\title{
Expression of Gast, Cckbr, Regla genes in rat duodenal epithelial cells upon long-term gastric hypoacidity and after a multiprobiotic administration
}

\author{
A. S. Dranitsina, U. V. Savko, K. O. Dvorshchenko, L. I. Ostapchenko \\ Educational and Scientific Center «Institute of Biology», \\ Taras Shevchenko National University of Kyiv \\ 64/13, Volodymyrska Str., Kyiv, Ukraine, 01601 \\ alevtina.dranitsina@gmail.com
}

\begin{abstract}
Aim. Determination of the Cckbr, Gast and Regla genes expression in rat duodenal epithelial cells upon longterm hypoacidity and with the administration of the multiprobiotic Symbiter. Methods. The experiments were carried out on white non-strain male rats. The hypoacidic state was induced through intraperitoneal injection of omeprazole for 28 days. The level of genes expression was determined by semi-quantitative analysis with RT-PCR Results. The elevation of mRNA levels of the Cckbr and Gast genes in rat duodenal villus and crypt epitheliocytes, the increased expression of the Regla gene in crypt epithelial cells were shown as well as the appearance of the Regla gene expression in villus epitheliocytes upon hypoacidic conditions were shown. The content of mRNAs of the above mentioned genes decreased or remained at the control level upon the treatment of hypoacidic rats with the multiprobiotic Symbiter. Conclusions. Long-term gastric hypoacidity is accompanied by the changes in expression of the Cckbr, Gast and Regla genes in rat duodenum, whereas upon administration of the multiprobiotic Symbiter the pattern of studied gene expression did not changed in the most cases.
\end{abstract}

Keywords: gastric hypoacidity, duodenal, expression of Cckbr, Gast, Regla genes, multiprobiotics.

Introduction. In recent decades, proton-pump inhibitors (PPI) of gastric parietal cells, such as omeprazole, appear to be the most effective and probably safe therapeutic agents for the acid-related disorders treatment [1-3]. The development of dysbiosis is one of the key consequences of long-term hypoacidity [3-5].

Colonization of gastrointestinal tract (GIT) by opportunistic microbiota forms stable sources of endogenous infection and in addition to the effect of hypergastrinemia promotes gastric carcinogenesis and tumorigenesis in other parts of GIT as well as in associated organs [3-7].

It is well known, that the Gast gene encodes the GIT hormone gastrin, which is expressed exclusively in both enteroendocrine G-cells of gastric antrum mucosa and proximal part of duodenum, and exerts a trophic impact

(C) Institute of Molecular Biology and Genetics, NAS of Ukraine, 2014 on some GIT cells $[4,8,9]$. According to the literature data, the overexpression and «adventive» expression of gastrin may be associated with the development of gastrinoma under most pathological conditions [8].

The Cckbr gene (encodes gastrin/cholecystokinin receptor type II or B - CCKBR) mediates certain physiological functions of gastrin [10]. To date, there is sufficient evidence for the presence of CCKBR protein in small intestine, but the majority of reports suggest that the normal duodenal cells are characterised by low levels of the Cckbr expression. On the other hand, a high expression level of the CCKBR protein is mostly found in clinical disorders as well as in certain GIT tumors [9].

The Regla gene gives rise to a regenerative protein, specifically - regenerating islet-derived protein 1a [1113]. This protein is localized in the small intestine Paneth cells, as well as in the non-mature columnar cells of human intestinal crypts, but has not been yet found 
in functional villous epithelium [12]. Therefore, such topographical distribution appears to be associated with the growth and differentiation processes of actively proliferating intestinal epithelium cells [13]. It has been also established that the Regla gene expression in highly differentiated villi may be connected to tumorigenesis [11-13].

In clinical trials it was proved that probiotics in general are able to cure dysbiotic states, as well as to instantly reduce GIT lesions ratio $[14,15]$. The multiprobiotics of the «Symbiter ${ }^{\circledR}$ acidophilic» concentrated group, also referred to as Symbiter, are characterized by action complexity, wide bioactivity array, high level of biological safety and close to that of natural human and animal microbial population composition [14, 15].

The analysis of recent scientific literature revealed lack of data on the pattern of above mentioned genes expression in duodenum under experimental or natural hypoacidic conditions. The data concerning possible probiotic effects on the gene expression in duodenal cells upon hypoacidity are also nearly absent.

Consequently, the aim of current investigation was to determine the expression of Cckbr, Gast and Regla genes in rat duodenal epithelial cells upon long-term injection of omeprazole and with «Symbiter» administration.

Materials and methods. The International recommendations on performance of medical and biological investigations with the use of animals according to European Convention for the Protection of Vertebrate Animals Used for Experimental and other Scientific Purposes were followed. Experiments were conducted on white non-strain male rats with initial weight around $180-200 \mathrm{~g}$.

All experimental animals were divided into four groups. The first one (control) consisted of rats injected with $0.2 \mathrm{ml}$ of physiological solution abdominally and $0.5 \mathrm{ml}$ of water orally. The second group was treated with «Symbiter» (manufactured by LLC «O. D. Prolisok») orally $(0.14 \mathrm{ml} / \mathrm{kg})$ for 28 days. In the third animal group hypoacidity was modelled by daily intraperitoneal injection of omeprazole $(14 \mathrm{mg} / \mathrm{kg})$ for 28 days [15]. Finally, the rats of the fourth experimental group were given the same dose of «Symbiter» simultaneously with omeprazole. Every experimental group consisted of 6 animals. The crypts and the villi of duodenal epithe- lial cells were extracted by a rapid low-temperature (4 $\left.{ }^{\circ} \mathrm{C}\right)$ method, which included intestine washing under the constant stirring in different buffers with the consequential gradual collection of villus or crypt fractions [16].

RNA was isolated following Chomczynski and Sacchi [17]. cDNA was synthesized in $20 \mu$ of reaction mix, containing $2 \mu \mathrm{g}$ of RNA, $1 \mathrm{mM}$ dNTP, $50 \mathrm{U}$ of reverse transcriptase «MultiScribeTM Reverse Transcriptase», the corresponding buffer, $20 \mathrm{U}$ of ribonuclease inhibitor «RNase Inhibitor» («Applied Biosystems», USA), and $20 \mathrm{pmol}(1.0 \mu \mathrm{M})$ of reverse primer. The synthesis was performed upon $37^{\circ} \mathrm{C}$ for $2 \mathrm{~h}$. Polymerase chain reaction was conducted in $30 \mu \mathrm{l}$ of the reaction mix containing $10 \mu \mathrm{l}$ of cDNA, the PCR buffer, $200 \mu \mathrm{M}$ of each dNTP, 30 pmol $(1.0 \mu \mathrm{M})$ of each primer, $2.5 \mathrm{mM}$ of $\mathrm{MgCl}_{2}$ and $1.5 \mathrm{U}$ of Taq DNA polymerase («iTaqTM», «Bio-Rad», USA).

The PCR amplifications consisted of the initial denaturing step of $95{ }^{\circ} \mathrm{C}$ for $3 \mathrm{~min}$, followed by 35 (28 for $A c t b$ gene was used as internal control of reaction due to its constitutive expression) cycles of $95^{\circ} \mathrm{C}$ for $45 \mathrm{~s}$, the annealing step (with the optimal annealing temperature): Cckbr (184 b. p., $59^{\circ} \mathrm{C}-45$ s), Gast $\left(310\right.$ b. p., $52^{\circ} \mathrm{C}-$ $40 \mathrm{~s}), \operatorname{Reg} 1 a\left(608\right.$ b. p., $\left.48^{\circ} \mathrm{C}-45 \mathrm{~s}\right)$ and $A c t b(521$ b. p., $49{ }^{\circ} \mathrm{C}-40 \mathrm{~s}$ ); the extending step at $72{ }^{\circ} \mathrm{C}$ for 1 min $15 \mathrm{~s}$ (for Cckbr, Regla) or $1 \mathrm{~min}$ (for Gast and Actb). The final extension step was performed upon $72{ }^{\circ} \mathrm{C}$ for $5 \mathrm{~min}$.

The following primer sequences were used for reactions:

for $C c k b r-$

forward - GCAAGCACGAGTATGGCAAA; reverse - TAGCACGGACCAGGTTTGTT;

for Gast forward - GCCCAGCCTCTCATCATC; reverse - GGGGACAGGGCTGAAGTG;

for Regla-

forward - AGCCTGCAGAGATTGTTGAC; reverse - CCATAGGGCAGTGAGGCAAG;

for $A c t b-$ forward - TGGGACGATATGGAGAAGAT; reverse - ATTGCCGATAGTGATGACCT.

Reproducibility of the amplification results was evaluated in the parallel experiments by the PCR reactions repetition with all animals and each primer at least three times. The separation of PCR products was performed electrophoretically in $1.6 \%$ agarose gel with $0.5 \times \mathrm{TBE}$ 
A
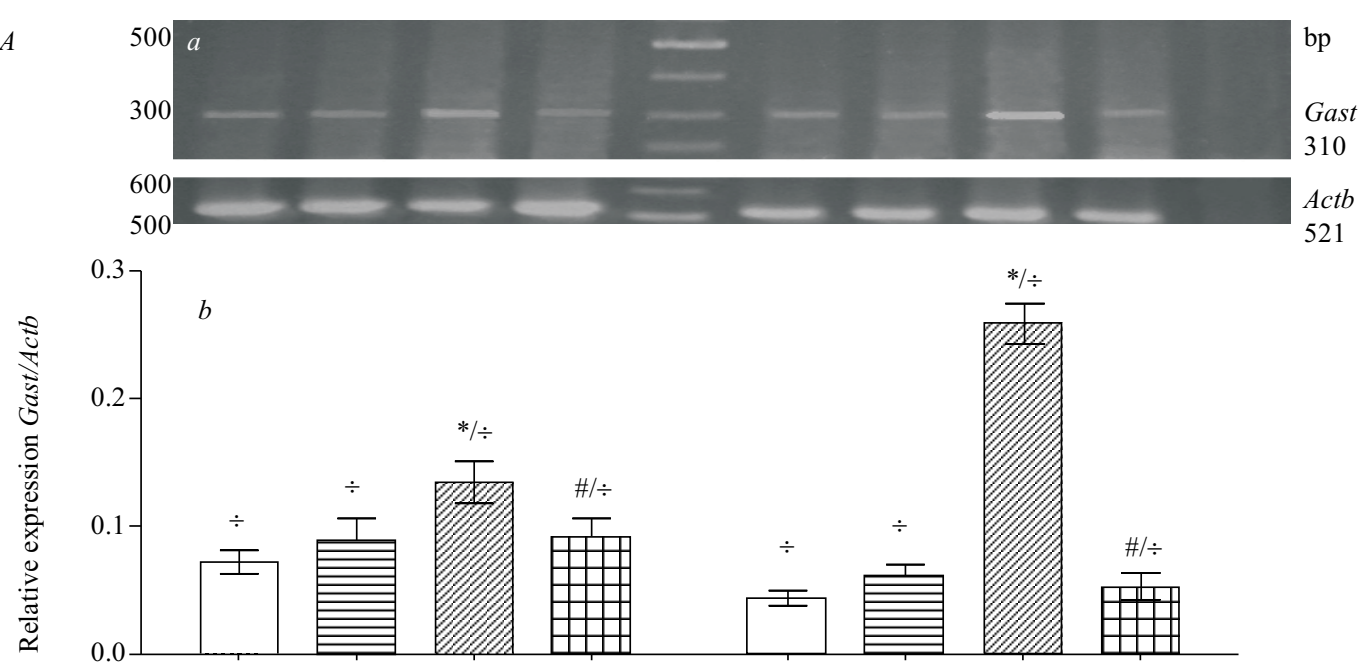

$B$
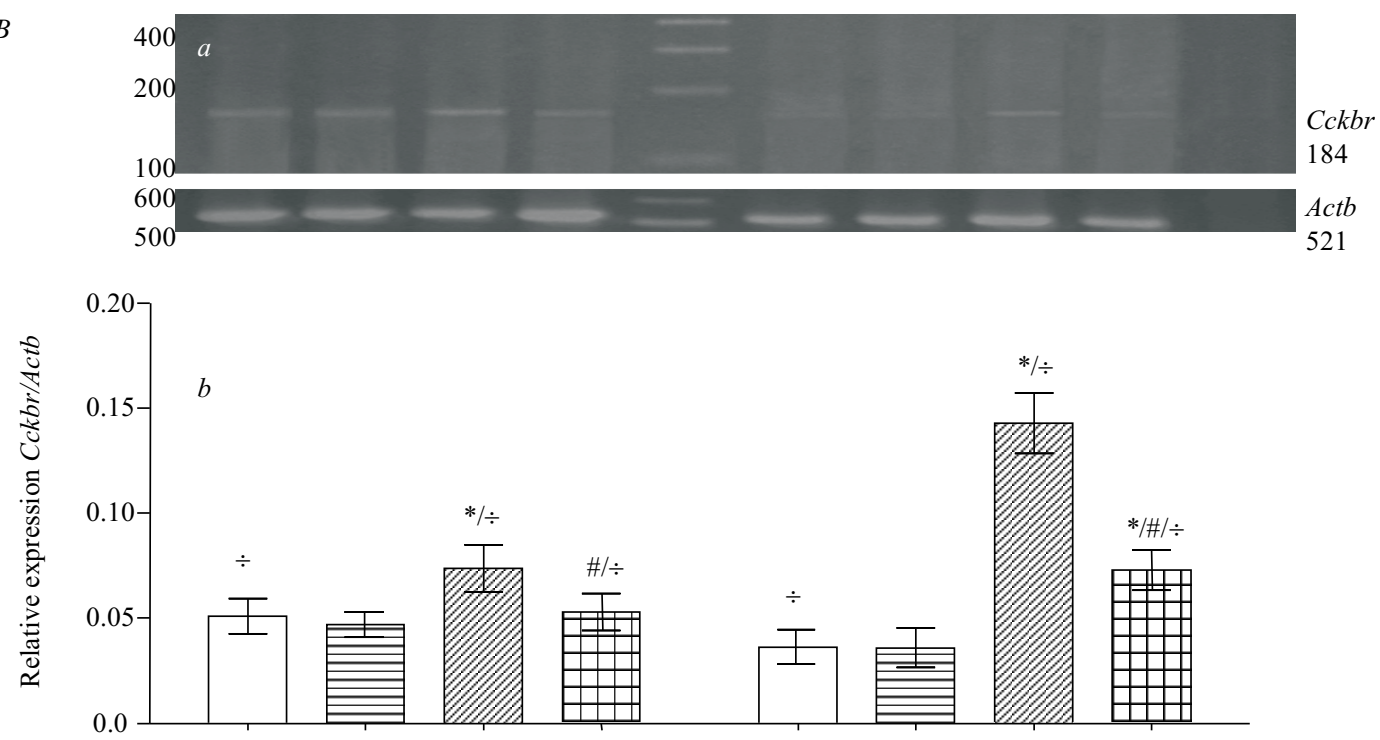

C
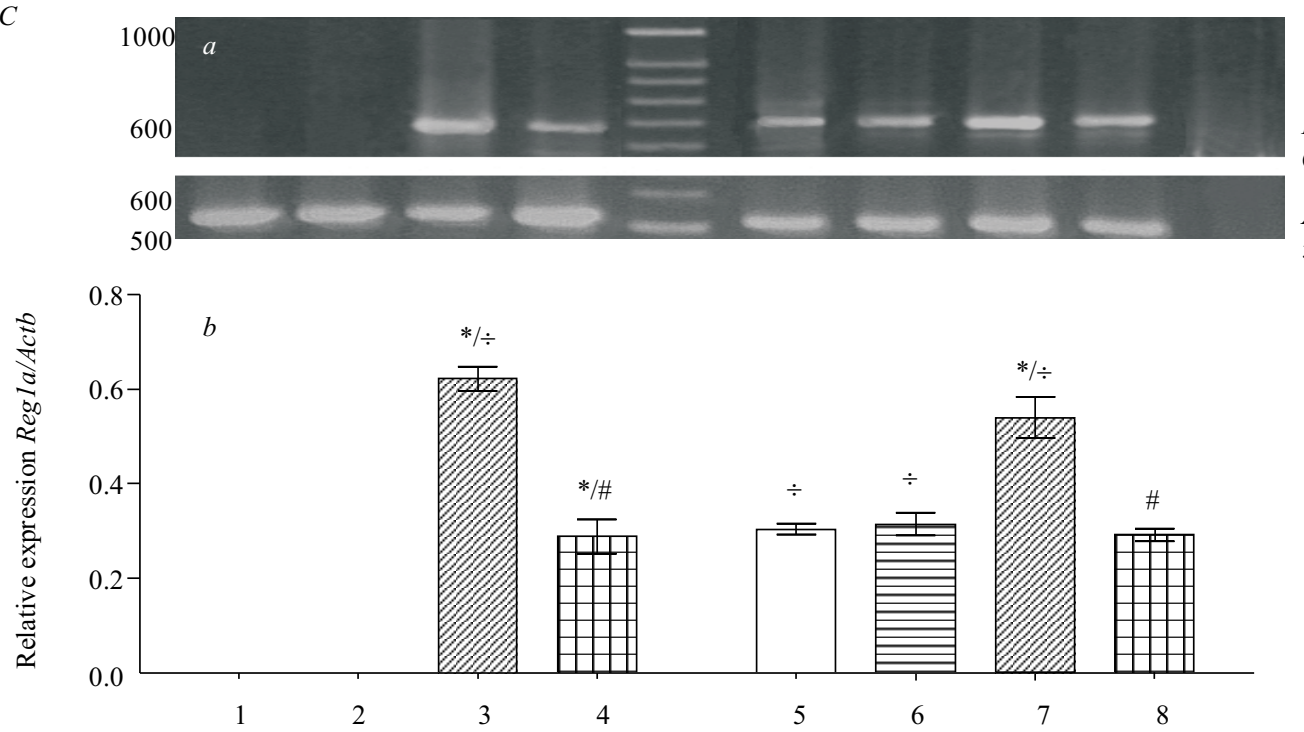

Level of Gast (A), Cckbr (B) and Regla $(C)$ genes mRNA in rat duodenum upon longterm hypoacidity and with the multiprobiotic administration: $a$ - RT-PCR electrophoregram $(M-$ molecular mass marker - «GeneRuRegla 1 er $^{\mathrm{TM}} 100$ bp DNA Ladder», 608 «Fermentas», Lithuania; NPCR - negative PCR control); $b$ - relative expression histogram $(*-p \leq 0.05$ in relation to control; $\#-\mathrm{p} \leq 0.05$ compared to the animals treated with omeprazole; $\div-\mathrm{p} \leq$ 0.05 ; villi in comparison with crypts). $A, B, C$ : villus epithelial cells: 1 - control; $2-$ Symbiter; 3 - omeprazole; 4 - omeprazole + Symbiter; crypt epithelial cells: 5 - control; 6 -Symbiter; 7 - omeprazole; 8 - omeprazole + Symbiter 
The levels of Gast, Cckbr, Regla genes mRNA in rat duodenal cells upon long-term hypoacidity and with the multiprobiotic administration $(m \pm S D, n=6)$

\begin{tabular}{|c|c|c|c|c|}
\hline Groups of animals & Epithelial cell types & Relative expression Gast/Actb & Relative expression $C c k b r / A c t b$ & Relative expression Regla/Actb \\
\hline \multirow[t]{2}{*}{ Control } & Villi & $0.072 \pm 0.0086 \div$ & $0.051 \pm 0.0078 \div$ & 0 \\
\hline & Crypts & $0.044 \pm 0.0056 \div$ & $0.036 \pm 0.0078 \div$ & $0.305 \pm 0.0110 \div$ \\
\hline \multirow[t]{2}{*}{ Symbiter } & Villi & $0.091 \pm 0.0145 \div$ & $0.047 \pm 0.0058$ & 0 \\
\hline & Crypts & $0.061 \pm 0.0080 \div$ & $0.036 \pm 0.0091$ & $0.314 \pm 0.0231 \div$ \\
\hline \multirow[t]{2}{*}{ Omeprazole } & Villi & $0.134 \pm 0.0155^{*} \div$ & $0.074 \pm 0.0107^{*} \div$ & $0.622 \pm 0.0247^{*} \div$ \\
\hline & Crypts & $0.259 \pm 0.0150 * \div$ & $0.143 \pm 0.0136^{*} \div$ & $0.540 \pm 0.0403 * \div$ \\
\hline \multirow[t]{2}{*}{ Omeprazole + Symbiter } & Villi & $0.092 \pm 0.0135 \# \div$ & $0.053 \pm 0.0084 \# \div$ & $0.289 \pm 0.0351 \#$ \\
\hline & Crypts & $0.053 \pm 0.0100 \# \div$ & $0.073 \pm 0.0091 * \# \div$ & $0.292 \pm 0.0135 \#$ \\
\hline
\end{tabular}

N o t e s. $\mathrm{SD}-$ standard deviation; $*-\mathrm{p} \leq 0.05$ related to control; $\#-\mathrm{p} \leq 0.05$ in comparison with animals treated with omeprazole; $\div-\mathrm{p} \leq 0.05$ villi in comparison with crypts.

buffer as described in Sambrook et al. [18]. Based on densitometry results, the ImageJ $1.45 \mathrm{~s}$ program was used for semi-quantitative analysis of amplicon expression. The indexes of mRNA expression for each sample were calculated following Konturek et al. [19].

The statistical processing of the experimental data was performed using GraphPad Prism 5.04 («Graph Pad Software Inc.», USA). The normal Gaussian distribution of the data was verified by the Shapiro-Wilk normality test. Two-way analysis of variance (two-way ANOVA) and Bonferroni post tests were performed with the data obtained. The statistical significance was set at $p \leq 0.05$. The reviewed data are expressed as means and standard deviations.

Results and discussion. mRNA of Gast gene was detected in the rat's duodenal villus and crypt epithelial cells in the control groups of investigated animals (Figure, $A$ ).

As seen in Table, the level of Gast gene expression was 1.9 times higher than the control value in villi and 5.9 times higher than in crypts of the animals treated only with omeprazole for 28 days $(\mathrm{p} \leq 0.05)$. Upon simultaneous administration of the multiprobiotic «Symbiter» this parameter was 1.5 and 4.9 times lower compared to the third experimental group $(\mathrm{p} \leq 0.05)$. In the rats treated only with «Symbiter» this value was similar to the control in both villus and crypt epitheliocytes of duodenum (Figure, $A$, Table).

As we have already mentioned, gastrin exerts a trophic impact on certain GIT cells $[4,8,9]$. In our experiments in hypoacidic conditions we demonstrated the elevation of the Gast mRNA level in villus epithelial cells as well as high expression level of this gene in immature crypts. The results obtained may be a sign of pathological hypertrophy in duodenal cells, which could lead to dystrophic, necrotic and sclerotic irreversible organ changes, accompanied by chronic inflammation [13, $20]$. As it is known from the literature data, overexpression and «adventive» expression of gastrin may be associated with the development of gastrinoma; it is a common feature of Zollinger-Ellison syndrome [8].

We demonstrated the Gast mRNA overexpression in duodenum upon the same hypoacidic conditions confirms our previous results concerning the Gast gene expression in hypoacidic rat pancreas [21]. Considering this fact, we can also assume a possible existence of neoplasia in duodenal epithelial cells at the later stages of the pathology development upon long-term use of PPI.

The mRNA of $C c k b r$ gene was detected in the rat duodenal villus and crypt epithelial cells in the control groups of investigated animals (Figure, $B$ ).

As seen from Table, the level of the Cckbr gene expression was 1.5 times higher compared to the control values in villi and 4 times higher than in crypts upon long-term hypoacidity $(\mathrm{p} \leq 0.05)$. In case of the simultaneous administration of the multiprobiotic «Symbiter» the parameter was respectively 1.4 and about 2 times lower than in the third group of animals $(\mathrm{p} \leq 0.05)$. In rats treated only with «Symbiter» there was no change of this value in both villus and crypt epitheliocytes of duodenum in comparison to the control one. 
The majority of reports suggest that the normal duodenum cells appear to express the Cckbr gene at low levels $[8,22]$. To date, the role of cholecystokinin as a small bowel and colon growth stimulator is not yet established [9]. So, we demonstrated the overexpression of $C c k b r$ gene in villus and particularly in crypt epithelial cells upon long-term hypoacidic conditions. The apparent high level of $C c k b r$ mRNA may be caused by the intensification of its expression by gastrin, because the latter, in addition to gastric secretion, is known to regulate proliferation of the cells expressing receptors for this ligand. Such regulation may be performed by stimulating the expression of early response genes as well as other growth-related genes $[9,22]$. The abundant expression of $C c k b r$ may be also associated with the pathological hypertrophy in duodenal cells and the intensification of duodenum inflammation [13]. On the other hand, a high expression level of the CCKBR protein is found in esophageal adenocarcinoma as well as in ileal carcinoid [9]. The results obtained by us this time appeared to be in agreement with our previous data about $C c k b r$ expression in rat pancreas upon hypoacidic conditions [21]. Thus, we can also suggest a possible neoplasia in duodenal epithelial cells at the later stages of the pathology development upon long-term omeprazole administration.

mRNA of Regla gene was detected in the rat duodenal crypts of the control group, although the mRNA of this gene was not found in this group villous epithelium (Figure, $C$ ).

So, in the functional villous epithelium of duodenum upon long-term hypoacidity we found the Regla gene mRNA. At the same time, the level of this gene in the fourth experimental group of rats was 2.2 times lower compared to the animals injected with omeprazole ( $\mathrm{p} \leq$ 0.05).

In crypt epithelium of the animals treated only with omeprazole for 28 days the level of Regla mRNA was 1.8 times higher than the control values $(\mathrm{p} \leq 0,05)$. Upon the simultaneous administration of the multiprobiotic «Symbiter» this parameter was approximately 1.9 times lower in comparison to the third group of animals $(\mathrm{p} \leq 0.05)$. In rats treated only with «Symbiter» this value was similar to the control (Figure, $C$, Table).

It is well known, that the main function of crypts is the cell reproduction control during intestinal epithelial tissue regeneration. Moreover, it is known, that the crypt base columnar cells can only proliferate. The mid-crypt columnar cells have the ability to both proliferation and differentiation, whereas the crypt top columnar cells never divide, but continue to differentiate and then move along the villi lines $[4,12]$. The Regla gene mRNA expression was observed in Paneth cells, in the glands of Lieberkuhn (crypts) and nonmature columnar cells of the human intestinal crypts, but never in the functional mature villous epithelium [13].

In our experiment we demonstrated the elevation of the Regla mRNA level in crypt epithelial cells upon hypoacidic conditions (Figure, $C$, Table). Based on these results it can be assumed that the inflammatory process in duodenum intensifies $[13,20]$. The appearance of Regla gene expression in duodenal villous cells of the rats treated only with omeprazole (Figure, $C$, Table) may be related to a possible neoplasia in epithelial cells at the later stages of the pathological process development $[11-13,20]$. Indeed, the Regla gene expression in response to gastrin has been reported in ECL cells (enterochromaffin-like cells) and may be involved not only in the gastric mucosal cell growth, but also in the tumor development [9].

Thus, the obtained changes in expression of Gast, $C c k b r$, Regla gene in rat duodenal villus and crypts epithelial cells should point out a possible development of teratoid displacements in duodenal tissue upon hypoacidic conditions due to the development of dysbiosis, which makes promoting influence on the gastrin secretion in rat's stomach and evaluates the effect of hypergastrinemia [4-9, 11-13, 15, 20,21], according to the results of different studies of patients treated with omeprazole [2, $6,7]$. Different rates of alterations of the above mentioned gene expression in villus and crypts epithelial cells appear to be determined by their structural and functional characteristics [4]. According to the literature data, a well-established early feature of some inflammatory diseases, including pathological intestine disorders, is the formation of crypt abscesses, containing neutrophils migrating across the epithelium into the crypt lumen [4].

The first among possible mechanisms of the «Symbiter» action on gene expression in rat duodenal cells, may be based on the ability of this multiprobiotic to liquidate dysbiosis and GIT bacterial colonization. As a 
result of this action, the burden of pathogenic microbiota is removed from GIT and associated organs $[14,15]$. Furthermore, the multicomponent probiotic «Symbiter» is able to increase the reduced glutathione synthesis de novo (the main low-molecular cellular antioxidant), which results in its higher content in both GIT and duodenum. Moreover, the «Symbiter» bacterial vital products (vitamins, exopolysaccharides, short chain fat acids, immune-response modulating agents, etc.) have certain antioxidant properties, so they can delay the oxidative stress development and decrease the intensity of inflammation and other pathological processes in duodenal cells $[14,15,23]$. From the results of corresponding studies, it may be suggested that the observed «Symbiter» effects can be linked not only to normalization of GIT microbiota, but also to restriction of hypergastrinemia effects $[5,15,21]$. However, the final acceptance or rejection of this hypothesis requires further real-time PCR analysis and other research techniques along with a usage of selective antagonists of gastrin receptor. It will allow us to clarify the consequences of hypergastrinemia and GIT bacterial colonization.

Conclusions. In summary, we have shown, that longterm experimental hypoacidity is accompanied by the changes of the Gast, Cckbr and Regla genes expression in the rat duodenal epithelial cells. The level of studied gene expression upon the simultaneous administration of the multiprobiotic «Symbiter» in most cases did not change in comparison to the control values. Based on the obtained data, it might be assumed, that the analyzed genes are involved in the development of the pathological processes in duodenum, so there may be a certain potential risk of duodenal carcinogenesis upon long-term use of omeprazole as well as, probably, of other PPI.

\section{Експресія генів Gast, Cckbr, Regla в епітеліоцитах} дванадцятипалої кишки щурів за умов тривалої шлункової гіпоацидності та за введення мультипробіотика

\section{А. С. Драницина, У. В. Савко, К. О. Дворщенко, Л. І. Остапченко}

Резюме

Mета. Дослідити експресію генів Cckbr, Gast i Regla у дванадияятипалій кишиі шурів за умов тривалої гіпоацидності та за введення мультипробіотика Симбітер. Методи. Досліди виконано на білих нелінійних щурах-самиях. Гіпоацидний стан моделювали інтраперитонеальним введенням омепразолу протягом 28 діб. $\mathrm{Pi}$ вень експресії генів визначали напівкількісним аналізом результатів ЗТ-ПЛР. Результати. Показано зростання рівня мРНК генів
Cckbr i Gast в епітеліоцитах ворсинок і крипт дванадиятипалої кишки щурів; підвищення рівня експресї гена Regla в епітеліоцитах крипт, а також появу експресії иуього гена в епітеліальних клітинах ворсинок за гіпоацидного стану. При введенні мультипробіотика Симбітер за тих же умов вміст мРНК досліджуваних генів зменшувався або був на рівні контрольних значень. Висновки. Стан тривалої шлункової гіпоацидності супроводжується зміною експресї̈ генів Cckbr, Gast i Regla у дванадияятипалій кишці шурів, тоді як за введення мультипробіотика Симбітер патерн експресії иих генів у більшості випадків подібний до контролю.

Ключові слова: илункова гіпоациність, дванадиятипала кишка, експресія генів Cckbr, Gast, Regla, мультипробіотики.

Экспрессия генов Gast, Cckbr, Regla в эпителиоцитах двенадцатиперстной кишки крыс в условиях длительной желудочной гипоацидности и при введении мультипробиотика

А. С. Драницина, У. В. Савко, Е. А. Дворщенко, Л. И.Остапченко Резюме

Цель. Исследовать экспрессию генов Cckbr, Gast u Regla в эпителиоцитах двенадцатиперстной кишки крыс в условиях длительной гипоацидности, а также при введении мультипробиотика Симбитер. Методы. Исследования проведены на белых нелинейных крысах-самиах. Состояние гипоацидности желудка моделировали интраперитонеальным введением омепразола в течение 28 дней. Уровень экспрессии генов определяли полуколичественным анализом результатов ОТ-ПЦР. Результаты. Показано повышение уровня мРНК генов Cckbr u Gast в эпителиоцитах ворсинок и крипт двенадиатиперстной кишки крыс; увеличение уровня экспрессии гена Regla в эпителиоцитах крипт, а также появление экспрессии этого гена в эпителиальных клетках ворсинок при гипоацидности. При введении мультипробиотика Симбитер в тех же условиях содержание мРНК проанализированных генов уменьшалось или было на уровне контрольных значений. Выводы. Состояние длительной желудочной гипоацидности сопровождается изменением экспрессии генов Cckbr, Gast u Regla в двенадияатиперстной кишке, тогда как при введении мультипробиотика Симбитер паттерн экспрессии исследованных генов в большинстве случаев близок к контролю.

Ключевые слова: желудочная гипоацидность, двенадиатиперстная кишка, экспрессия генов Cckbr, Gast, Regla, мультипробиотики.

\section{REFERENCES}

1. Shin JM, Vagin O, Munson K, Kidd M, Modlin IM, Sachs G. Molecular mechanisms in therapy of acid-related diseases. Cell $\mathrm{Mol}$ Life Sci. 2008;65(2):264-81.

2. Bateman DN, Colin-Jones D, Hartz S, et al. Mortality study of 18000 patients treated with omeprazole. Gut. 2003;52(7):942-6.

3. Thomson AB, Sauve MD, Kassam N, Kamitakahara H. Safety of the long-term use of proton pump inhibitors. World J Gastroenterol. 2010;16(19):2323-30.

4. Barrett KE, Ghishan FK, Merchant JL, Said HM, Wood JD. Physiology of the gastrointestinal tract. $4^{\text {th }}$ edition. New York: Acad. Press, 2006; 2080 p.

5. Friis-Hansen L. Achlorhydria is associated with gastric microbial overgrowth and development of cancer: lessons learned from the gastrin knockout mouse. Scand J Clin Lab Invest. 2006; 66(7):607-21. 
6. Jensen RT. Consequences of long-term proton pump blockade: insights from studies of patients with gastrinomas. Basic Clin Pharmacol Toxicol. 2006;98(1):4-19.

7. Jianu CS, Fossmark R, Viset T, et al. Gastric carcinoids after longterm use of a proton pump inhibitor. Aliment Pharmacol Ther. 2012;36(7):644-9.

8. Burkitt MD, Varro A, Pritchard DM. Importance of gastrin in the pathogenesis and treatment of gastric tumors. World J Gastroenterol. 2009;15(1):1-16.

9. Dufresne $M$, Seva C, Fourmy D. Cholecystokinin and gastrin receptors. Physiol Rev. 2006;86(3):805-47.

10. Ashurst HL, Varro A, Dimaline R. Regulation of mammalian gastrin/CCK receptor (CCK2R) expression in vitro and in vivo. Exp Physiol. 2008;93(2):223-36.

11. Sekikawa A, Fukui H, Fujii S, et al. Possible role of REG Ialpha protein in ulcerative colitis and colitic cancer. Gut. 2005;54(10): 1437-44.

12. Sekikawa A, Fukui H, Fujii S, et al. REG Ialpha protein mediates an anti-apoptotic effect of STAT3 signaling in gastric cancer cells. Carcinogenesis. 2008;29(1):76-83.

13. Bernard-Perrone FR, Renaud WP, Guy-Crotte OM, et al. Expression of REG protein during cell growth and differentiation of two human colon carcinoma cell lines. J Histochem Cytochem. 1999;47(7):863-70.

14. Culligan EP, Hill C, Sleator RD. Probiotics and gastrointestinal disease: successes, problems and future prospects. Gut Pathog. 2009;1(1):19.

15. Tsyriuk OI, Beregova TV. Effect of omeprazole-induced hypergastrinemia on the basal gastric secretion in rats. Bulletin of biological and medical issues. 2007;(3):38-43.

16. Flint N, Cove FL, Evans GS. A low-temperature method for the isolation of small-intestinal epithelium along the crypt-villus axis. Biochem J. 1991;280 ( Pt 2):331-4.
17. Chomczynski P, Sacchi N. Single-step method of RNA isolation by acid guanidinium thiocyanate-phenol-chloroform extraction. Anal Biochem. 1987;162(1):156-9.

18. Sambrook J, Russell DW. Molecular cloning: a laboratory manu- al. New York, Cold Spring Harbor Lab. Press, $3^{\text {rd }}$ edition, $2001 ; 2344$ p.

19. Konturek PC, Brzozowski T, Pierzchalski P, et al Activation of genes for spasmolytic peptide, transforming growth factor alpha and for cyclooxygenase (COX)-1 and COX-2 during gastric adaptation to aspirin damage in rats. Aliment Pharmacol Ther. 1998;12(8):767-77.

20. Planell N, Lozano JJ, Mora-Buch R, et al. Transcriptional analysis of the intestinal mucosa of patients with ulcerative colitis in remission reveals lasting epithelial cell alterations. Gut. 2013;62 (7):967-76.

21. Vakal SE, Dvorshchenko KO, Dranitsina AS, Borodina TV, Ostapchenko LI. Expression of Cckbr, Gast, Regl $\alpha, T g f \beta 1$ genes in rat pancreas upon long-term hypoacidity and with administration of multiprobiotic «Symbiter ${ }^{\circledR}$ acidophilic» concentrated. Biopolym Cell. 2012;28(6):461-7.

22. Lay JM, Jenkins C, Friis-Hansen L, Samuelson LC. Structure and developmental expression of the mouse CCK-B receptor gene. Biochem Biophys Res Commun. 2000;272(3):837-42.

23. Lutgendorff F, Trulsson LM, van Minnen LP, et al. Probiotics enhance pancreatic glutathione biosynthesis and reduce oxidative stress in experimental acute pancreatitis. Am J Physiol Gastrointest Liver Physiol. 2008;295(5):G1111-21.

Received 12.11.13 